\title{
DURATION AND CONCENTRATION OF 1-METHYLCYCLOPROPENE TREATMENT: IMPACT ON RIPENING AND SHELF LIFE OF PARTIALLY RIPENED BANANAS
}

\author{
F. MORADINEZHAD ${ }^{1^{*}}$ \\ *E-mail: fmoradinezhad@birjand.ac.ir
}

Received: Dec. 07, 2019. Revised: Jan 21, 2020. Accepted: Jan. 25, 2020. Published online: Mar 06, 2020

\begin{abstract}
In order to improve the quality and extend the shelf life of bananas after gassing with ethylene at commercial treatment during transportation and storage the simultaneous application of ethylene and 1-methylcyclopropene were examined. Fruit were treated with $100 \mu \mathrm{L}^{-1}$ of ethylene for two consecutive days as a control, followed by 20 min ventilation each day, or simultaneously exposed to 1-MCP at different concentrations $(30,100$ or $300 \mathrm{~nL} \mathrm{~L}^{-1}$ on the first day or second day, or treated with 1-MCP alone on the third day at $22^{\circ} \mathrm{C}$. Fruit from each treatment were used to evaluate external and internal quality parameters and shelf life. The results showed that shelf life increased significantly, compared to the control when 1-MCP was applied coincidently with ethylene in the second day and reapplied alone in the third day. The highest increase in shelf life (125\%) was obtained when 1-MCP was applied on the second day at $30 \mathrm{~nL} \mathrm{~L} \mathrm{~L}^{-1}$
\end{abstract}

simultaneously with ethylene and at $300 \mathrm{~nL} \mathrm{~L} \mathrm{~L}^{-1}$ alone on the third day, compared to the control in both harvest months. We conclude that simultaneous application of 1-MCP is more effective than the more common method of extending banana shelf life through application of 1-MCP after ethylene treatment.

Keywords: 1-MCP; ethylene; firmness; quality; weight loss.

\section{INTRODUCTION}

Bananas are a common everyday fruit in most countries around the world. They are the staple food for over 400 million people in the developing world (Lopez-Gomez et al., 1997). When bananas are harvested at a mature stage that can withstand the rigors and duration of transport and

\footnotetext{
${ }^{1}$ Department of Horticultural Science, College of Agriculture, University of Birjand, Birjand, Iran
} 
then treated with ethylene to promote ripening before sale, their quality is increased (Saltveit, 2004). However, autocatalytic ethylene production causes unwanted changes, such as over-ripening of fruit. Hence, there is a requirement to control the action of ethylene through methods, such as inhibition of ethylene perception. Although ethylene can be deleterious to fresh produce, it can also be used to improve the quality of horticultural products by promoting and ensuring uniform ripening (Saltveit, 1999). Both the concentration and duration of exogenous ethylene significantly impact the response of bananas (Inaba and Nakamura, 1986; Wills et al., 2001; Moradinezhad et al., 2006), as does fruit maturity (Burg and Burg, 1965; Moradinezhad et al., 2008 ).

Commercially, bananas are harvested in green stage and after shipping to Iran, ripening is induced by gaseous ethylene during transportation in different trucks or at destination in ripening room to start ripening process. The bananas come from Ecuador or the Philippines to Iran after 20-25 days of shipping at $13-14^{\circ} \mathrm{C}$. However, ripening process is very fast and a quick distribution is required to avoid from over-ripening during shelf life of bananas at retail shops and at home and also to reduce postharvest losses. As the ripening room temperature is higher than green life storage, after ethylene gassing special care is required particularly cold chain, which is not provided in developing countries due to lack of proper pack houses and refrigerated trucks for transportation. In recent years, effective agents for blocking the ethylene receptor have been discovered and hold the promise of being a new way of controlling ripening, senescence and other ethylene responses (Sisler and Serek, 1999). 1-methylcyclopropene (1-MCP) is the best example of synthetic cyclopropenes which block ethylene receptors and prevent ethylene effects in plant tissues for extended periods (Sisler and Serek, 1997).

The ability of 1-MCP to delay ripening of pre-climacteric bananas has been demonstrated (Golding et al., 1999; Sisler and Serek, 1997), as well as the time-concentration-temperature dependence of this response (Macnish et al., 2000). However, the efficacy of 1-MCP was variable to some extent in these reports. A variety of factors may need to be considered when using 1-MCP on bananas, including concentration, timing, developmental stage, ethylene, temperature and harvesting season. All of these factors are significant, as the final quality of fruit can be determined by them.

Although considerable research (Bagnato et al., 2003; Harris et al., 2000; Macnish et al., 2000; Pelayo et al., 2003; Moradinezhad et al., 2010; Botondi et al., 2014) has been devoted to the application of 1-MCP at different concentrations or durations in climacteric fruits including bananas, rather less attention has been paid to the timing of 1-MCP exposure in relation to ethylene application. While 1-MCP 


\section{F. MORADINEZHAD}

application before ethylene initiation of ripening, may be useful in preventing premature ripening during extended periods of banana handling and transport (Macnish et al., 2000), an extension of shelf life only appears possible when 1-MCP is applied in the earliest phase of banana ripening within 24 to $48 \mathrm{~h}$ of ethylene treatment (Bagnato et al., 2003). However, increasing the 1-MCP application time post-ethylene treatment may have some potential (Jiang et al., 1999). Our previous report (Moradinezhad et al., 2009) regarding to the effect of 1-MCP treatment on the quality and shelf life of Cavendish bananas, which was cultivated on Australia, confirmed by a recent study (Botondi et al., 2014) that reported simultaneous application of ethylene and 1-MCP at proper concentrations before commercial treatment of ethylene can extend banana storage during overseas shipping. However, the response of Cavendish bananas to the application of 1-MCP and ethylene simultaneously has not been examined in the imported fruit in Iran. Hence, the aim of this study was to establish whether altering timing of $1-\mathrm{MCP}$ application and also its different concentrations could improve the quality and shelf life of bananas.

\section{MATERIAL AND METHODS}

\section{Plant material and preparation}

Mature and green Cavendish banana fruit were purchased from a commercial banana supplier in Hormozgan province, Iran, during 2018 and transported to the University of Birjand within two days.
To prepare fruit, bananas from the middle section of each hand were collected. Damaged and defective fruits were eliminated and were then immersed in $100 \mathrm{ppm}$ sodium hypochlorite for $2 \mathrm{~min}$ for surface disinfection. Fruit were then air-dried before random allocation of fruit to each treatment. For each replicate within a treatment groups of six individual fruit were treated in $10 \mathrm{~L}$ plastic containers containing $100 \mathrm{~g} \mathrm{Ca}$ $(\mathrm{OH})_{2}$ (carbon dioxide scrubber) and a $20 \mathrm{ml}$ saturated $\mathrm{KNO}_{3}$ solution to maintain a relative humidity of $90 \%$, as described in Moradinezhad et al. (2008).

\section{Simultaneous application of 1-MCP and ethylene treatment}

Bananas were transferred to the laboratory in September and December 2018. After preparation, fruit were treated with ethylene at $100 \mu \mathrm{L} \mathrm{L}^{-1}$ for two consecutive days as a control or simultaneously with $1-\mathrm{MCP}$ at different concentrations $\left(30,100\right.$ or $\left.300 \mathrm{~nL} \mathrm{~L}^{-1}\right)$ on the first or second day. To allow comparison with other experiments and to determine the effect of simultaneous application, a treatment where 1-MCP was applied separately after ethylene treatment was also included. As a result, bananas were treated with $1-\mathrm{MCP}$ at different concentrations, duration and timing in eight different treatments as shown in Table 1. Containers were ventilated for 20 min each day. After treatment, fruit were removed from containers and placed in plastic bags with the lid slightly open and placed at $22^{\circ} \mathrm{C}$ with $90 \%$ RH. $1-\mathrm{MCP}$ was created, introduced to the treatments and measured as described in Moradinezhad et al. (2006).

\section{Quality assessments}

A number of 10 fruit from each treatment were used to measure external 


\section{DURATION AND CONCENTRATION OF 1-METHYLCYCLOPROPENE TREATMENT IN BANANAS}

parameters, and the remaining fruit allocated to each treatment were used to assess internal quality measurable characteristics at colour stage 6 (CSIRO, 1972), as described previously in Moradinezhad et al. (2010).

\section{Statistical assessments}

A completely randomised block experimental design was used in experiments, with three replicates. Data were analysed with the GenStat program (version 12, 2010, VSN International, Ltd., UK) using the general analysis of variance (ANOVA). A least significant difference test $(p=0.05)$ was used to determine significant differences between means. Data of each harvest was analysed individually.

Table 1 - Treatments used to study the effect of simultaneous application of 1-MCP and ethylene. Fruit were treated with ethylene (E) for two consecutive days (control), or simultaneously with 1-MCP (M) on the first or second day, or treated on the third day.

\begin{tabular}{ccc}
\hline First day & Second day & Third day \\
\hline$E$ & $E$ \\
\hline$E+M_{300}$ & $E$ \\
\hline$E$ & $E+M_{300}$ \\
\hline$E$ & $E+M_{300}$ & $M_{100}$ \\
\hline$E$ & $E+M_{300}$ & $M_{300}$ \\
\hline$E$ & $E+M_{100}$ & $M_{100}$ \\
\hline$E$ & $E+M_{30}$ & $M_{300}$ \\
\hline$E$ & $E$ & $M_{300}$ \\
\hline${ }^{*} E=E$ Ethylene concentration at $100 \mu L^{-1} ;{ }^{* *}$ \\
$M=1-M C P$ at subscript concentration $(30,100$ \\
or $\left.300 n L L^{-1}\right)$
\end{tabular}

\section{RESULTS}

\section{Shelf life}

Simultaneous application of 1-MCP with ethylene particularly on the second day of ethylene treatment generally increased shelf life regardless of banana harvest month (Fig. 1). Even though fruit treated with ethylene only (control) were similar regardless of harvest time (that is, 4.2 days in September, compared with 4.4 days in December).

Shelf life increased significantly, compared to the control, when 1-MCP was applied coincidently with ethylene in the second day and reapplied alone in the third day or applied only in the third day, in both harvest times. However, application of 1-MCP at all treatments significantly increased shelf life in December. When 1-MCP was applied at $300 \mathrm{~nL} \mathrm{~L}^{-1}$ in both the second day (simultaneously with ethylene) and third day (alone) fruit did not ripen, such that they were still green after one week, and therefore there was no data to present for this treatment in figures.

The highest increase in shelf life (125\%) was obtained when 1-MCP was applied on the second day at 30 $\mathrm{nL} \mathrm{L^{-1 }}$ simultaneously with ethylene and at $300 \mathrm{~nL} \mathrm{~L}^{-1}$ alone on the third day, compared to the control in both harvest months.

\section{Firmness}

Firmness of control fruit was slightly higher in Septemberharvested $(102 \mathrm{kPa})$ fruit than in December-harvested $(90 \mathrm{kPa})$ fruit (Fig. 2). Application of 1-MCP simultaneously with ethylene in the second day, followed by 1-MCP treatment in the third day gave lower firmness, compared to the control in September, but not in the December 


\section{F. MORADINEZHAD}

harvest. 1-MCP increased firmness in December-harvested fruit when 1-MCP was applied at $300 \quad \mathrm{~nL}^{-1}$ simultaneously with ethylene in the first day.
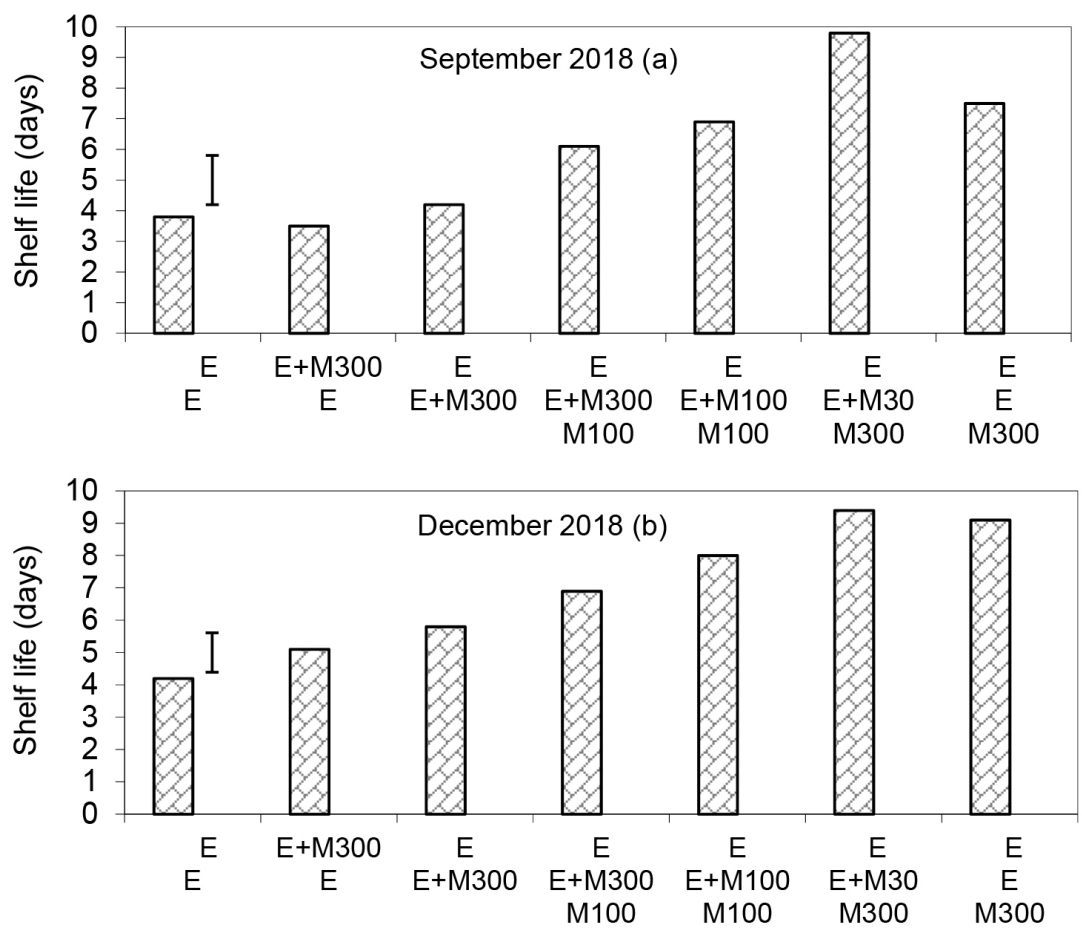

Figure 1 - Effect of simultaneous application of 1-MCP and ethylene on shelf life of Cavendish bananas ripened at $22^{\circ} \mathrm{C}$ in September 2018 (a), December 2018 (b). $E=$ ethylene at $100 \mu L^{-1}$ and $M=1-M C P$ at subscript concentration $(30,100$ or $\left.300 \mathrm{~nL} \mathrm{~L}^{-1}\right)$. Vertical bars represent LSD values at the $5 \%$ level.

\section{Overall acceptability}

The response of treated fruit to both ethylene and 1-MCP treatments and their simultaneous application was similar in both September and December harvested fruit to some extent (Fig. 3).Although the overall quality was higher in September than December harvested fruit. Simultaneous application of 1-MCP at $300 \mathrm{~nL} \mathrm{~L}^{-1}$ with ethylene on the second day, followed by $100 \mathrm{~nL} \mathrm{~L}^{-1}$ on the third day, had no significant effect on taste acceptability; however, in both harvested time application of $1-\mathrm{MCP}$ at $300 \mathrm{~nL} \mathrm{~L}^{-1}$ on the first day significantly reduced the taste and the overall acceptability of Cavendish bananas, compared to the control. 

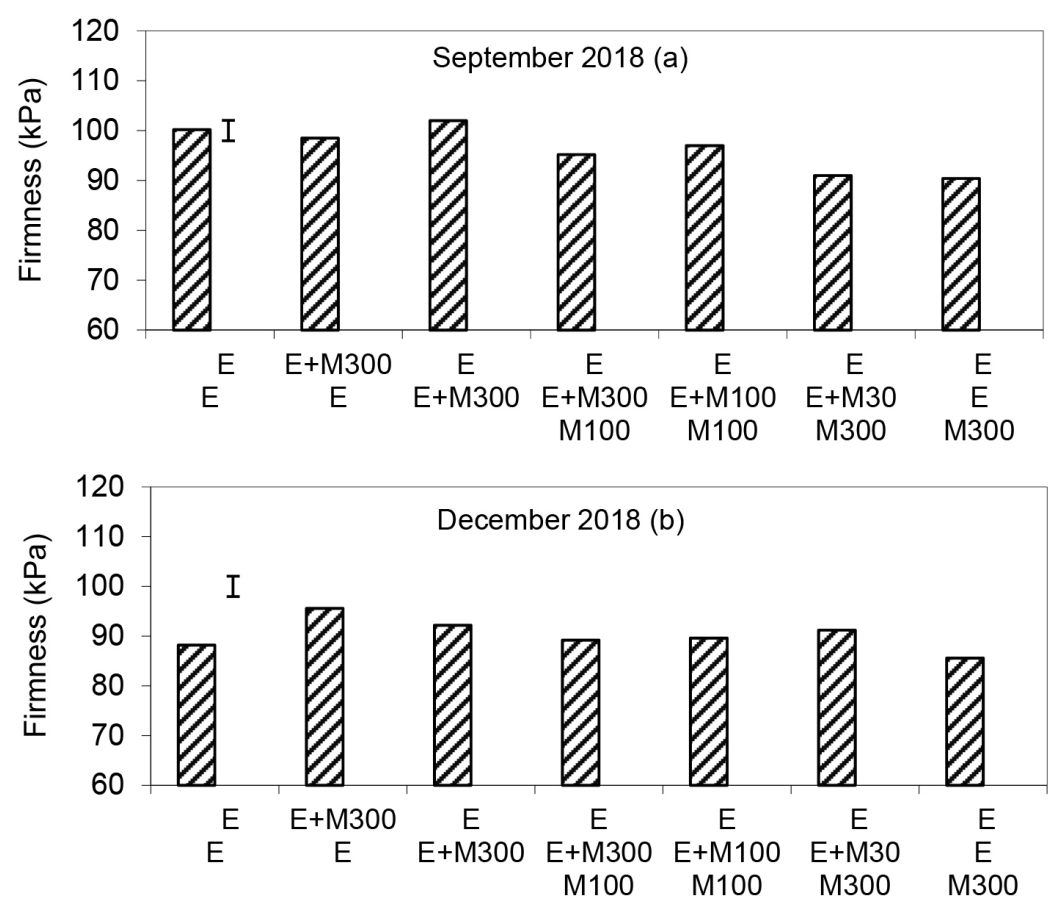

Figure 2 - Effect of simultaneous application of 1-MCP and ethylene on pulp firmness of Cavendish bananas ripened at $22^{\circ} \mathrm{C}$ in September 2018 (a), December 2018 (b). $E=$ ethylene at $100 \mu L^{-1}$ and $M=1-M C P$ at subscript concentration (30, 100 or $300 \mathrm{~nL} \mathrm{~L}^{-1}$ ). Vertical bars represent LSD values at the $5 \%$ level.

\section{Weight loss}

The percentage of weight loss was higher in the control fruit from the September harvest compared to the December harvest. Weight loss of simultaneously-treated fruit with ethylene and 1-MCP increased significantly, compared to the control in September. In December weight loss significantly decreased, compared to the control, except where 1-MCP was applied at $100 \mathrm{~nL} \mathrm{~L}^{-1}$ in the second day with ethylene and alone in the third day (Fig. 4).

\section{Total soluble solids}

Total soluble solids of control fruit were similar at both harvest times. Simultaneous application of 1-MCP with ethylene on the first or second day decreased TSS significantly at most treatments. However, there were no similar trends in September and December (Fig. 5). 


\section{F. MORADINEZHAD}
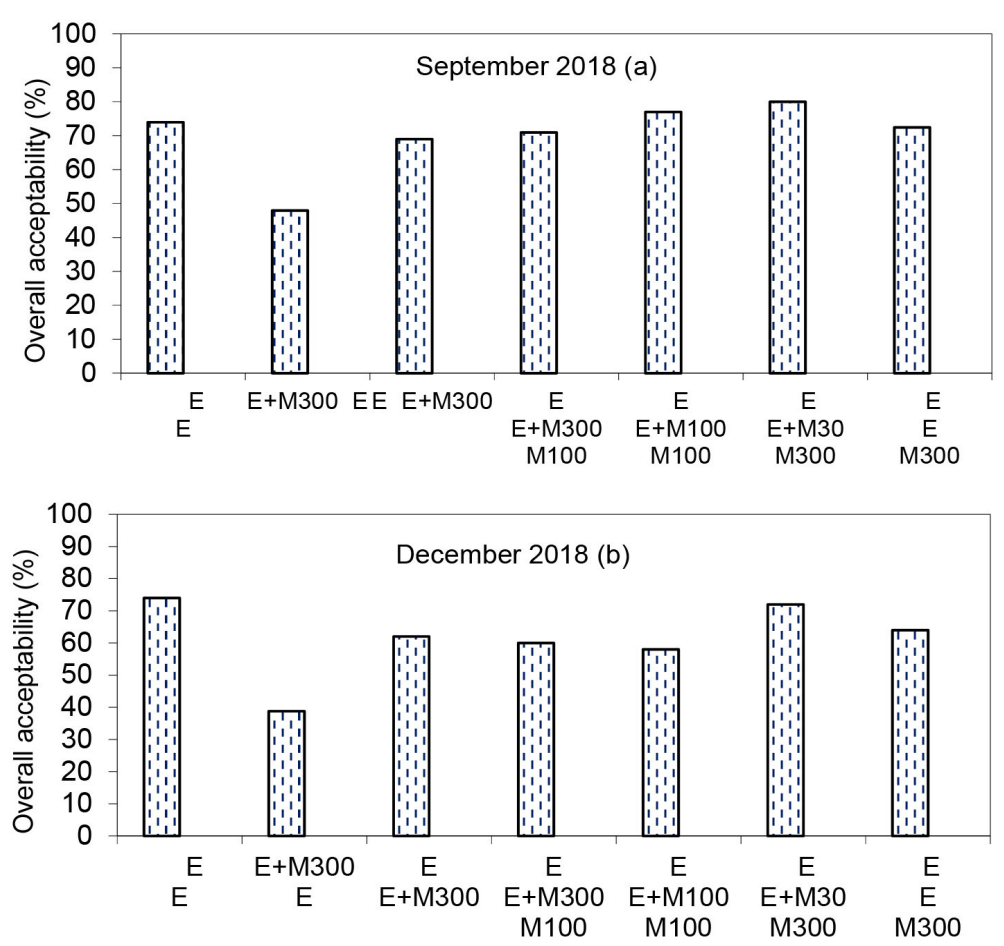

Figure 3 - Effect of simultaneous application of 1-MCP and ethylene on overall acceptability (\%) of Cavendish bananas ripened at $22^{\circ} \mathrm{C}$ in September 2018 (a),

December 2018 (b). E = ethylene at $100 \mu L^{-1}$ and $M=1-M C P$ at subscript concentration $\left(30,100\right.$ or $\left.300 \mathrm{~nL} \mathrm{~L}^{-1}\right)$. Vertical bars represent LSD values at the $5 \%$ level.

\section{DISCUSSION}

The findings of this research has confirmed previous research that less than $100 \mu \mathrm{L} \mathrm{L}^{-1}$ of ethylene was sufficient to induce ripening (Burg and Burg, 1965; Inaba and Nakamura, 1986). The concentration $\times$ time response to applied ethylene is the basis of recommendations for the commercial ripening of bananas. However, the response of fruit to $1-\mathrm{MCP}$ treatment was highly dependent on not only the exogenous ethylene concentration and application, but also on the timing of 1-MCP treatment and the duration of its application. The results were also consistent with results described previously by Moradinezhad et al. (2008) that indicated time of year at harvest influences the response of bananas to 1-MCP treatment. These effects are more than likely due to differences in the timing of preharvest factors and subsequent alteration in the sensitivity of banana fruit to applied ethylene during the year and their interaction with the timing of 1-MCP application. 

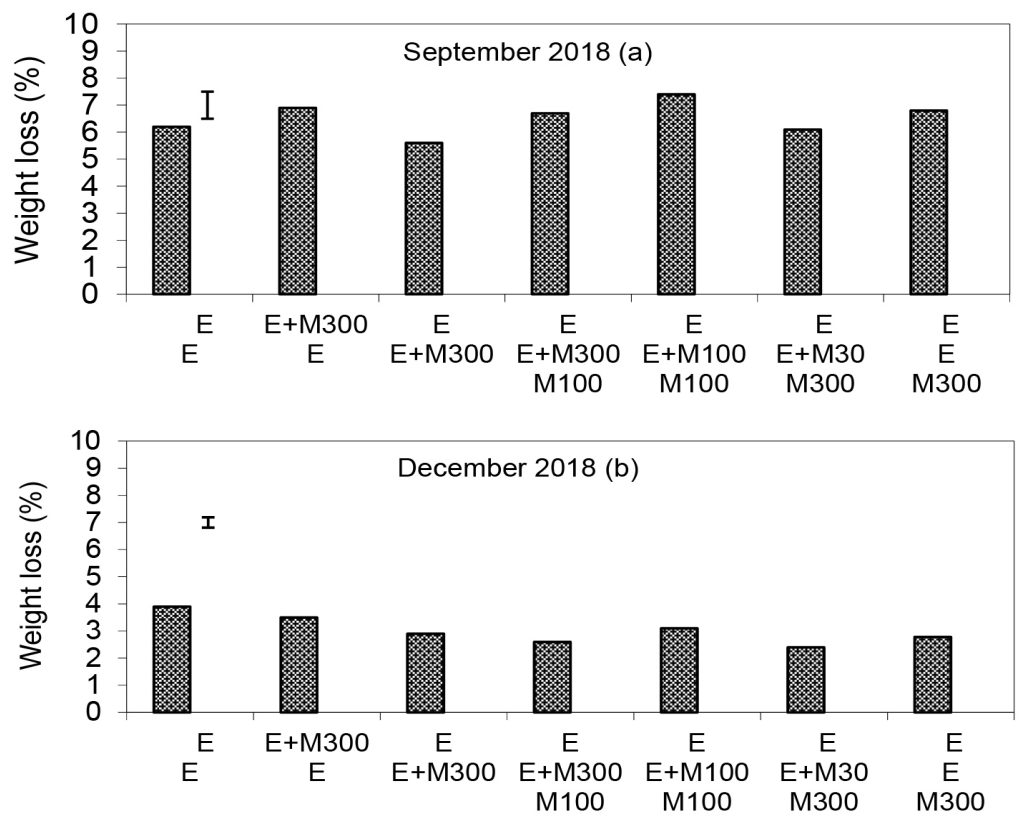

Figure 4 - Effect of simultaneous application of 1-MCP and ethylene on weight loss (\%) of whole fruit of Cavendish bananas ripened at $22^{\circ} \mathrm{C}$ in September 2018 (a), December 2018 (b). E = ethylene at $100 \mu L^{-1}$ and $M=1-M C P$ at subscript concentration $\left(30,100\right.$ or $\left.300 \mathrm{~nL} \mathrm{~L}^{-1}\right)$. Vertical bars represent LSD values at the $5 \%$ level.

Simultaneous application of ethylene and 1-MCP gave a greater increase in shelf life and improved fruit quality than application of 1-MCP to the partially ripened bananas after two days ethylene treatment. This may be a result of either using 1-MCP at low concentration at an earlier stage of banana ripening during the second day of treatment and coincidently with ethylene or increasing the 1-MCP treatment exposure duration from 1 to 2 days or both. It has been reported that 1-MCP competes with ethylene for receptors when both are applied simultaneously (Sisler and Serek, 2006). Because 1-MCP has relatively greater affinity than ethylene for ethylene-binding sites (Jiang et al., 1999), it was hypothesised that application of 1-MCP at low concentration and simultaneously with ethylene will reduce the speed of fruit ripening. The results obtained support the conclusions of Jiang et al. (1999), who stated that 1-MCP should be applied in the earliest phase of banana ripening initiation to give an extension to ripening. However, this was to some extent in contrast to the findings of Bagnato et al. (2003), who reported that exposure periods from 24 to $72 \mathrm{~h}$ did not affect the efficacy of 1-MCP in quality and shelf life of 


\section{F. MORADINEZHAD}

bananas. Application of 1-MCP for a longer duration than $24 \mathrm{~h}$ had a significant effect on the assessments. This revealed the importance of timing of 1-MCP application and also continued application of 1-MCP at optimum concentration.
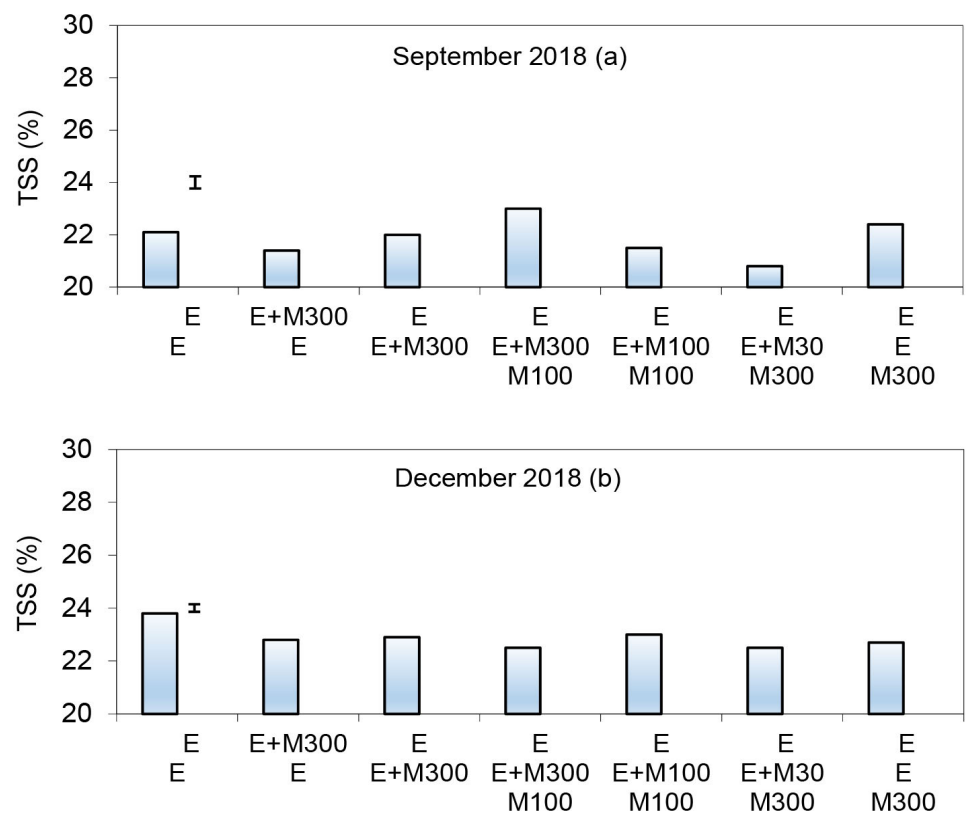

Figure 5 - Effect of simultaneous application of 1-MCP and ethylene on total soluble solids (TSS \%) of Cavendish bananas ripened at $22^{\circ} \mathrm{C}$ in September 2018 (a), December 2018 (b). $E=$ ethylene at $100 \mu L^{-1}$ and $M=1-M C P$ at subscript concentration $\left(30,100\right.$ or $\left.300 \mathrm{~nL} \mathrm{~L}^{-1}\right)$. Vertical bars represent LSD values at the $5 \%$ level.

The results also demonstrated that timing of 1-MCP application influences the inhibitory effect of $1-\mathrm{MCP}$ in extending the fruit shelf life. In addition, the current study supported the findings of Macnish et al. (2000), who stated that there is considerable potential to manipulate banana ripening by varying the concentration and duration of 1-MCP treatment and altering the relative timing of 1-MCP application.

Similarly, Botondi et al. (2014) found that simultaneous application of
1-MCP and ethylene during transportation in early stage of ripening had positive effect on quality maintenance and shelf life extension of bananas that were treated after about two weeks with ethylene gas for commercial ripening. Thus, 1-MCP must be applied at an optimum concentration, duration and time to provide maximum benefit to extend green life or shelf life of Cavendish bananas. 


\section{DURATION AND CONCENTRATION OF 1-METHYLCYCLOPROPENE TREATMENT IN BANANAS}

\section{CONCLUSIONS}

The results demonstrated that both simultaneous application of 1-MCP and ethylene and reapplication of 1-MCP extend the shelf life of Cavendish bananas.

Thus, concentration, duration, and timing of 1-MCP exposure must be determined with ethyleneapplication in mind to ensure the consistency in response of bananas to 1-MCP treatment and also to maximise the benefit of 1-MCP application.

Acknowledgment. The author would like to give special thanks to MSc graduates (2017-2018) of Department of Horticultural Science, University of Birjand, for their valuable cooperation in data collection in this research.

\section{REFERENCES}

Bagnato, N., Barrett, R., Sedgley, M. \& Klieber, A. (2003). The effects on the quality of Cavendish bananas, which have been treated with ethylene, of exposure to 1-methylcyclopropene. Int.J. Food Sci.Techn, 38(7): 745-750, DOI: 10.1046/j.1365-2621.2003.00726.x

Botondi, R., De Sanctis, F., Bartoloni, S. \& Mencarelli, F. (2014). Simultaneous application of ethylene and 1-MCP affects banana ripening features during storage. J.Sci. Food Agric., 94(11): 2170-2178, DOI: 10.1002/jsfa.6599

Burg, S.P. \& Burg, E.A. (1965). Relationship between ethylene production and ripening in bananas. Bot.Gaz., 126(3): 200-204.

CSIRO (1972). Banana ripening guide. Division of food research circular, 8 ,
North Ryde, N.S.W.: Commonwealth Scientific and Industrial Research Organization, Australia.

Golding, J.B., Shearer, D., McGlasson, W.B. \& Wyllie, S.G. (1999). Relationships between respiration, ethylene, and aroma production in ripening banana. J.Agric.Food Chem., 47(4): 1646-1651, DOI: 10. 1021/jf980906c

Harris, D.R., Seberry, J.A., Wills, R.B.H. \& Spohr, L.J. (2000). Effect of fruit maturity on efficiency of 1-methylcyclopropene to delay the ripening of bananas. Postharvest Biol.Technol., 20(3): 303-308, DOI: 10.1016/S0925-5214(00)00150-2

Inaba, A. \& Nakamura, R. (1986). Effect of exogenous ethylene concentration and fruit temperature on the minimum treatment time necessary to induce ripening in banana fruit. J.Jpn.Soc.Hortic.Sci., 55(3): 348354, DOI: 10.2503/jjshs.55.348

Jiang, Y.M., Joyce, D.C. \& Macnish, A.J. (1999). Extension of the shelf life of banana fruit by 1 -methylcyclopropene in combination with polyethylene bags. Postharvest Biol.Technol., 16(2): 187-193, DOI: 10.1016/S0925 $-5214(99) 00009-5$

Jiang, Y., Joyce, D.C. \& Macnish, A.J. (1999). Responses of banana fruit to treatment with 1-methylcyclopropene. Plant Growth Regul., 28(2): 77-82, DOI: $10.1023 / \mathrm{A}: 1006222631666$

López-Gómez, R., Campbell, A., Dong, J.-G., Yang, S.-F., \& Gómez-Lim, M.A. (1997). Ethylene biosynthesis in banana fruit: isolation of a genomic clone to ACC oxidase and expression studies. Plant Sci., 123(1-2): 123-131, DOI: 10.1016/SO 168-9452(97)04578-0

Macnish, A.J., Joyce, D.C., Hoffman, P.J., Simons, D.H. \& Reid, M.S. (2000). 1-Methylcyclopropene treatment efficacy in preventing ethylene perception in banana fruit and grevillea and waxflower flowers. Aust.J.Exp.Agric., 40(3): 471-481. 


\section{F. MORADINEZHAD}

Moradinezhad, F., Able, A.J., Sedgley, M. \& Klieber, A. (2006). Concentration and duration of ethylene treatment influences the response of banana to 1-methylcyclopropene. Acta Hortic., 712: 747-752, DOI: 10.176 60/Acta Hortic.2006.712.96, IV International Conference on Managing Quality in Chains-The Integrated View on Fruits and Vegetables Quality.

Moradinezhad, F., Sedgley, M., Klieber, A. \& Able, A.J. (2008). Variability of responses to 1-methylcyclopropene by banana: influence of time of year at harvest and fruit position in the bunch. Ann.App.Biol., 152(2): 223234, DOI: 10.1111/j.1744-7348.20 07.00206.x

Moradinezhad, F., Klieber, A., Able, A.J. \& Sedgley, M. (2009). Timing of 1-methylcyclopropene exposure in relation to ethylene application influences shelf life of Cavendish banana. ActaHortic., 877: 305-310, DOI: $10.17660 /$ ActaHortic.2010.877. 36, VI International Postharvest Symposium.

Moradinezhad, F., Sedgley, M. \& Able, A.J. (2010). Effect of pre-ripening chilling temperatures on ripening, shelf life and quality of bananas treated with 1-methylcyclopropene. Int.J. Food Sci.Tech., 45(2): 312318, DOI: 10.1111/j.1365-2621.20 09.02137.x

Pelayo, C., de B Vilas-Boas, E.V., Benichou, M. \& Kader, A.A. (2003). Variability in responses of partially ripe bananas to 1-methylcyclopropene. Postharvest Biol.Technol., 28(1): 75-
85: DOI: $10.1016 / \mathrm{S} 0925-5214(02)$ 00124-2

Saltveit, M.E. (1999). Effect of ethylene on quality of fresh fruits and vegetables. Postharvest Biol. Technol., 15(3): 279-292.

Saltveit, M.E. (2004). Effect of 1-methylcyclopropene on phenylpropanoid metabolism, the accumulation of phenolic compounds, and browning of whole and fresh-cut 'iceberg' lettuce. Postharvest Biol.Technol., 34(1): 7580, DOI: 10.1016/j.postharvbio.2004. 05.001

Sisler, E.C. \& Serek, M. (1997). Inhibitors of ethylene responses in plants at the receptor level: recent developments. Physiol. Plant., 100(3): 577-582, DOI: 10.1111/j.1399-3054. 1997.tb03063.x

Sisler, E.C. \& Serek, M. (1999). Compounds controlling the ethylene receptor. Bot. Bull.Acad.Sin., 40: 1-7.

Serek, M., Woltering, E.J., Sisler, E.C., Frello, S. \& Sriskandarajah, S. (2006). Controlling ethylene responses in flowers at the receptor level. Biotechnol.Adv., 24(4): 368381, DOI: 10.1016/j.biotechadv. 2006.01.007

Wills, R.B.H., Warton, M.A., Mussa, D.M.D.N.,\& Chew, L.P. (2001). Ripening of climacteric fruits initiated at low ethylene levels. Aust.J. Exp.Agric., 41(1): 89-92, DOI: 10. 1071/ea00206. 